\title{
LIČKE PJEŠAČKE POSTROJBE AUSTROUGARSKE VOJSKE U BORBAMA TIJEKOM 1918. GODINE
}

\author{
Nikola Tominac \\ Ulica Bože Huzanića 76 \\ HR 10370 Dugo Selo \\ nikola.tominac@gmail.com
}

\author{
UDK: 94(497.52Lika)“1918“ \\ 323.2(497.5)(091) \\ Pregledni članak \\ Ur.: 2018-11-22
}

Ovaj je prilog posvećen stotoj obljetnici Prvoga svjetskog rata i pripadnicima ličke 79. pješačke pukovnije zajedničke vojske iz Otočca (K.u.K. Otočaner Infaterieregiment Graf Jellačić Nr. 79.), poznatije kao "Jelačićevci" i 26. domobranske pješačke pukovnije iz Karlovca iz 42. domobranske pješačke divizije u čijem je sastavu bila bojna Ličana iz Gospića. ${ }^{1}$ U njemu je opisano njihovo sudjelovanje u zadnjoj godini rata.

$\mathrm{Na}$ temelju raspoložive stručne literature i izvorne arhivske građe iz fundusa Austrijskoga državnog arhiva - Österreichisches Staatsarchiv (ÖeStA) - Kriegsarchiv (KA) i Hrvatskog državnog arhiva u Zagrebu (HDA), prvenstveno iz sačuvane operativne dokumentacije, izvještaja o bitkama, listama gubitaka, matičnih knjiga umrlih i ostale dostupne dokumentacije, autor obrađuje tijek bitaka tijekom 1918. godine. Vojna terminologija prilagođena je sadašnjoj službenoj hrvatskoj terminologiji, a ondje gdje to nije bilo moguće navedeni su usporedno hrvatski i austrougarski pojmovi, osobito za vojne činove i formacije.

Ključne riječi: Hrvatska vojna povijest, Prvi svjetski rat, Jugozapadno bojište, 79. pješačka pukovnija zajedničke vojske "Grof Josip Jelačić" Otočac, K.u.K. 48. pješačka divizija (K.u.K. 48 ID), 42. domobranska pješačka divizija, 26. domobranska pješačka pukovnija Karlovac.

\section{Uvod}

Južnotirolsko (Planinsko) bojište bilo je jedno od najtežih i najsloženijih bojišta na Talijanskom ratištu. Za talijanske oružane snage to je ključna karika obrane: ako ga protivnik osvoji, stvorit će iznimnu prednost za ulaz u Venetsku ravnicu i izbiti na jadransku obalu. Talijani su daleko ranije uočili stratešku važnost planine Monte Grappe, osobito zbog namjera da se protivničke snage spuste iz Tirola prema moru, što je bio jedan od austrougarskih planova.

1 M. POJIĆ, 2001, 168. 
Talijansko preventivno utvrđivanje Grappe počelo je već tijekom 1916. godine u vrijeme XII. Sočanske bitke. Crta obrane na južnom rubu masiva već je uglavnom bila dovršena i oslanjala se ponajprije na moćno naoružanu podzemnu tvrđavu na samom vrhu Mt. Grappe. Nju će braniti najelitnije postrojbe i o njihovim sposobnostima ovisit će budućnost daljnjih operacija i konačan uspjeh u ratu.

Tijekom zime i ljeta 1918. godine na šire područje Asiaga (Južni Tirol) s Istočnog bojišta pristigla je glavnina hrvatskih postrojbi. Zagrebačka 42. domobranska pješačka divizija ${ }^{2}$ dolazi u Grupu armija Conrad u veljači 1918. U sastavu ove divizije je i 26. domobranska pješačka pukovnija iz Karlovca s Gospićkom bojnom. Treba napomenuti da je 79. pješačka pukovnija iz Otočca stigla na područje Južnog Tirola tijekom proboja kod Kobarida u jesen 1917. godine. 15. lipnja 1918. godine 42. domobranska pješačka divizija (DomPD) ${ }^{3}$ je u sastavu XIII. korpusa/11. armije, a 79. pješačka pukovnija je u 95. pješačkoj brigadi iz sastava 48. pješačke divizije (XV. korpus iz sastava 11. armije). U to su vrijeme "Jelačićevci" bili u korpusnoj pričuvi. ${ }^{4}$

\section{Bitka na visoravni Sedam općina ${ }^{5}$ u Južnom Tirolu}

Lipanjske bitke na Jugozapadnom bojištu još su uvijek jedna od kontroverznih odluka austrougarskog vojnog vrha. Još su uvijek otvorena brojna pitanja oko same koncepcije napada i načina provedbe. Treba napomenuti da su se na Jugozapadnom bojištu tijekom 1918. godine nalazile dvije snažne vojne grupacije: brdsko područje pokrivala je Grupa armija Conrad, a područje uz rijeku Piave Grupa armija Borojević. Austrougarske snage opterećivao je velik problem s opskrbom, prvenstveno s hranom i streljivom. Nedostatak ugljena i radne snage je negativno utjecao na proizvodnju oružja i streljiva kao i ostalih

2 U njezinu su sastavu hrvatske 25, 26, 27. i 28. domobranska pješačka pukovnija.

3 Najčešće korištene vojne kratice u tekstu: K.u.K. - zajednička vojska (Kaiserlicheskönigliches Heer), AOK - austrougarsko vrhovno zapovjedništvo (Armeeoberkommando), PBrig - pješačka brigada (Infanteriebrigade), PD - pješačka divizija (Infanteriedivision), DomPD domobranska pješačka divizija, general major $(\mathrm{GM})$ - prvi generalski čin u rangu hrvatskoga brigadnog generala, slijede generali s "tri zvjezdice" ovisno o rodu ili službi: feldzeugmeister (FZM) - general topništva, odnosno tehničkih snaga. Najviši generalski čin u austrougarskoj vojsci bio je generaloberst (GO) - general pukovnik te (general) feldmarschall (G)FM - feldmaršal (maršal).

4 Österreich-Ungarns letzter Krieg, 1914. - 1918. (ÖULK) Vol. 7, Das Kriegsjahr 1918, 1938, Prilog 3.

5 U njemačkoj terminologiji: Sieben Gemeinde, a u talijanskoj: Sette Comuni. 


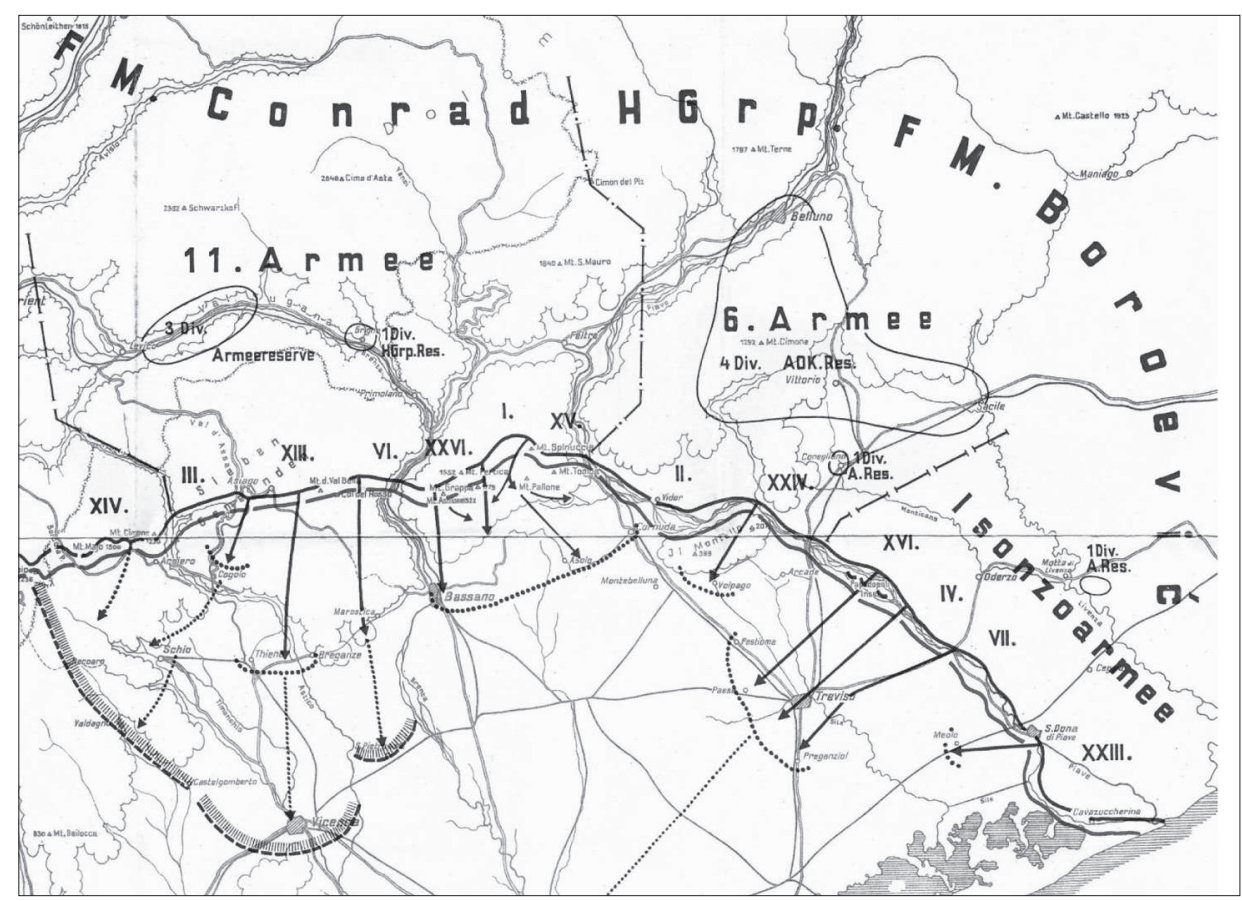

Sl. 1. Razmještaj austrougarskih snaga na Jugozapadnom bojištu i plan napada iz proljeća 1918. godine (izvor: ÖULK VII, 1938, Prilog 10, dio)

vojnih potrepština. Iako je tada bilo dovoljno streljiva, nije bilo jamstva da su zalihe dovoljno velike za veće vojne aktivnosti. U državi je racionirana potrošnja hrane i dolazi do sve većeg nezadovoljstva stanovništva, a vojska također gladuje.

U ožujku 1918. zamišljeno je da će se glavni napad odvijati između rijeka Astica i Piave. Kodni naziv ove operacije bio je "Operacija Albrecht". U međuvremenu su prispjele značajne snage s Istočnog bojišta, među njima i hrvatske divizije iz zagrebačkog XIII. korpusa. ${ }^{6} \mathrm{U}$ planskim razradama uporabe snaga zadaće zagrebačkog XIII. korpusa bile su osvajanje uzvisina u širem području gradića Asiaga: Mt. Kaberlabu, Mt. Cavalletto, Mt. Cimone i Corno i izbijanje do južnoga ruba šumske zone. Te je zadaće trebala dijelom provesti hrvatska 42. domobranska pješačka divizija podmaršala pl. Soretića. ${ }^{7}$

\footnotetext{
Österreich-Ungarns letzter Krieg, 1914. - 1918. (ÖULK) Vol. 7, Das Kriegsjahr 1918, 1938, 237. i Prilog 15.
} 1938, 189.

6 Österreich-Ungarns letzter Krieg, 1914. - 1918. (ÖULK) Vol. 7, Das Kriegsjahr 1918, 


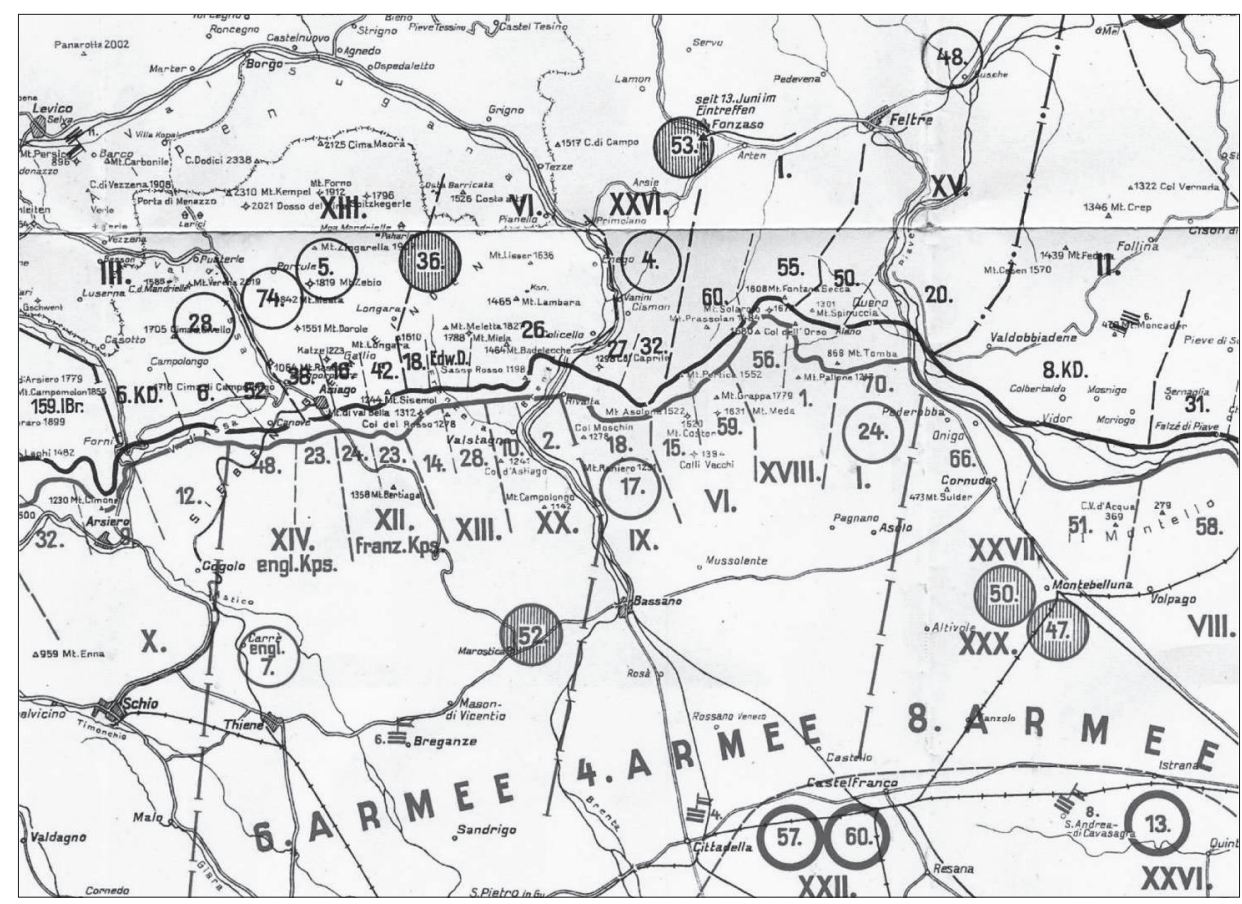

S1. 2. Detaljan razmještaj snaga 15. lipnja 1918. Domobrani su u sastavu 42. DomPD/ XIII. korpusa kod Asiaga, a "Jelačićevci" su u sastavu 48. PD/XV. korpusa kod sela Feltre (izvor: ÖULK VII, 1938, Prilog 13, dio)

Krajem travnja i svibnja definirani su konačni planovi i uporaba svih snaga, a time i 11. armije. Za nas su važne zadaće snaga zapadno od rijeke Brente gdje je zagrebački XIII. korpus zajedno s III. i VI. korpusom s visoravni Sedam općina (Sieben Gemeinde) trebao imati težište u napadu sa ciljem izbijanja u Venetsku ravnicu, osvojiti gradić Thienne i izbiti do strateški vrlo važnog grada Vicenze. Hrvatska 42. domobranska pješačka divizija razmještena je ispred gradića Asiaga. ${ }^{8}$

Bojište 11. armije između Astica i Piave podijeljeno je na dva zasebna pravca: zapadno od rijeke Brente napad se trebao odvijati s platoa Sedam općina (Sieben Gemeinde) kod gradića Asiaga kroz šumovitu zonu preko uzvisina koje se uzdižu južno od grada i nadalje preko planinskog područja prema Venetskoj

8 Österreich-Ungarns letzter Krieg, 1914. - 1918. (ÖULK) Vol. 7, Das Kriegsjahr 1918, 1938, 225. 
nizini. Drugi, pomoćni pravac obuhvaćao je područje proboja s šireg područja Mt. Grappe prema gradiću Bassano.

Na visoravni Sedam općina (Sieben Gemeinde) neprijatelj je stajao na rubu šuma šireg područja oko Asiaga u obrambenim položajima sa snažnom artiljerijom koji su po svim standardima bili izvrsno uređeni. Zapovjednici austrougarskih brigada su izvijestili viša zapovjedništva o snazi ovih utvrda: Šumsko područje na kojem je XIII. korpus trebao provesti težišni pravac napada bilo je zaštićeno snažno utvrđenim područjem i kontinuiranim linijama. Betonska gnijezda sa strojnicama dobro se međusobno pokrivaju, a kaverne s prolazima dubokim 15 metara pažljivo su maskirane mahovinom i teško su uočljive. ${ }^{9}$ Osim Talijana, tu su bile i britanske i francuske snage. Ovdje će se, po prvi put u povijesti, austrougarske pukovnije naći u borbi s britanskim vojnicima.

U noći 14. i 15. lipnja, pukovnije iz osam divizija iz svih zemalja višenacionalne Dunavske monarhije bile su razmještene na visoravni Sedam općina (Sieben Gemeinde) u kontinuiranoj, gotovo ravnoj crti i spremne za napad. Zapovjednik grupe armija feldmaršal (FM) Conrad izdao je vojnicima vrlo snažan proglas: Prošavši kroz sve zimske oluje, istovremeno pokazujući istinsku predanost $i$ ljudsku upornost, ugledali ste sunčane ravnice Italije. Trenutak koji ste željeli sada je ovdje .... Dobrobit, budućnost i čast naše velike, drevne $i$ voljene zajedničke domovine sada su u vašim rukama ... S čvrstim samopouzdanjem vas pozivam - idemo naprijed! ${ }^{10}$

Oko 3 sata ujutro austrougarska artiljerija je započela svoju paklenu simfoniju. Sat vremena kasnije započela je neprijateljska protuvatra. Prašina i dim kovitlali su se nad krajolikom. Vidljivost se počela poboljšavati tek oko 6 sati. Artiljerijska bitka, koju su obje strane vodile uz ogroman utrošak streljiva, postigla je svoj najveći intenzitet. Artiljerijska priprema za napad djelovala je gotovo posvuda tako da neprijateljska artiljerija nije bila ušutkana, što će bitno utjecati na ishod idućih borbi.

Oko sedam sati ujutro pješaštvo je krenulo naprijed u čitavoj širini bojišta na visoravni. Do 9 sati u zapovjedništvu 11. armije stekao se dojam da "trenutno sve ide po planu"11. XIII. korpus osvojio je prvu neprijateljsku liniju i nastavio napredovati. Sve divizije su velikim elanom prodrle u prvu neprijateljsku liniju.

9 Österreich-Ungarns letzter Krieg, 1914. - 1918. (ÖULK) Vol. 7, Das Kriegsjahr 1918, 1938, 235.

10 Österreich-Ungarns letzter Krieg, 1914. - 1918. (ÖULK) Vol. 7, Das Kriegsjahr 1918, 1938, 241.

11 Österreich-Ungarns letzter Krieg, 1914. - 1918. (ÖULK) Vol. 7, Das Kriegsjahr 1918, 1938, 242. 
Napade su ometali mnoga skrivena strojnička gnijezda i žestoki protunapadi britanskih i francuskih snaga zbog čega je došlo do usporavanja napredovanja. Austrougarske snage izbile su do linije Cesuna - sjeverozapadni rub Mt. Lemerle te Mga. Fassa, Turco, Cm. Ecker, Mt. Melago i sjeverno od Col. di Aresi. Tu su se u borbe uključile i protivničke zrakoplovne eskadrile. ${ }^{12}$

Stanje se naglo promijenilo u poslijepodnevnim satima. Jedna za drugom počele su pristizati loše vijesti. U zoni odgovornosti zagrebačkog XIII. korpusa odbačene su dvije divizije, dok se istočno krilo korpusa - 42. domobranske pješačke divizije (26. karlovačka i 28. osječka pješačka pukovnija) još uvijek držalo na uzvisini Mt. Nasa. Zapovjednik korpusa general Csanady morao je ojačati te snage, osobito na području oko sela Gallio. Na istočnom krilu korpusa pokraj Col d'Ecchelea povlače se snage zbog čega je zapovjedništvo armije bilo primorano uzeti 71. PBrig iz hrvatske 36 . pješačke divizije, koja je bila u pričuvi, i staviti je u nadležnost VI. korpusa kako bi obranili osvojeno područje. Nakon krvavih borbi tijekom noći niži zapovjednici izvijestili su svoje uspravnice da je zbog velikih gubitaka i premoći protivnika stanje njihovih vojnika dosta upitno. ${ }^{13} \mathrm{Na}$ istočnom krilu XIII. korpusa hrvatska 42. domobranska pješačka divizija krenula je tijekom jutra u napad i ušla u rovove kote 1094 - kapelica kod kod s. Pennar (jugoistočno od Asiaga), koju je čuvala francuska 24. pješačka divizija/XII k. Domobrani su u šest pokušaja pokušali probiti neprijateljsku obranu, ali su na kraju zbog slabe artiljerijske pripreme uspjeli postići tek mali napredak. ${ }^{14}$

Neuspjesi 11. armije u Južnom Tirolu bili su vrlo pogubni jer se vojska morala povlačiti pod teškim protunapadima protivnika. Stoga je FM Conrad bio prisiljen pregrupirati svoje snage i iz strategijskih pričuva prebaciti dio snaga na prednji dio bojišta. Vijesti o porazu 11. armije imale su vrlo štetne učinke na odluke načelnika Glavnog stožera GO Arza, koji je nakon svega bio uvjeren da bi bilo besmisleno ponoviti napad jer su postrojbe bile istrošene i pretrpjele teške gubitke i ostale bez streljiva. Neuspjeh 11. armije izazvao je dileme napustiti li ofenzivu ili ne. Za neke nove pripreme trebalo je dosta vremena i novih snaga kojih nije bilo. Cilj je bio zadržati dostignute položaje, osobito 11. armije. Treba li krenuti u novi napad s rijeke Piave? Za taj je plan

12 Österreich-Ungarns letzter Krieg, 1914. - 1918. (ÖULK) Vol. 7, Das Kriegsjahr 1918, 1938, 244.

13 Österreich-Ungarns letzter Krieg, 1914. - 1918. (ÖULK) Vol. 7, Das Kriegsjahr 1918, 1938, 243.

14 Österreich-Ungarns letzter Krieg, 1914. - 1918. (ÖULK) Vol. 7, Das Kriegsjahr 1918, 1938, 245. 


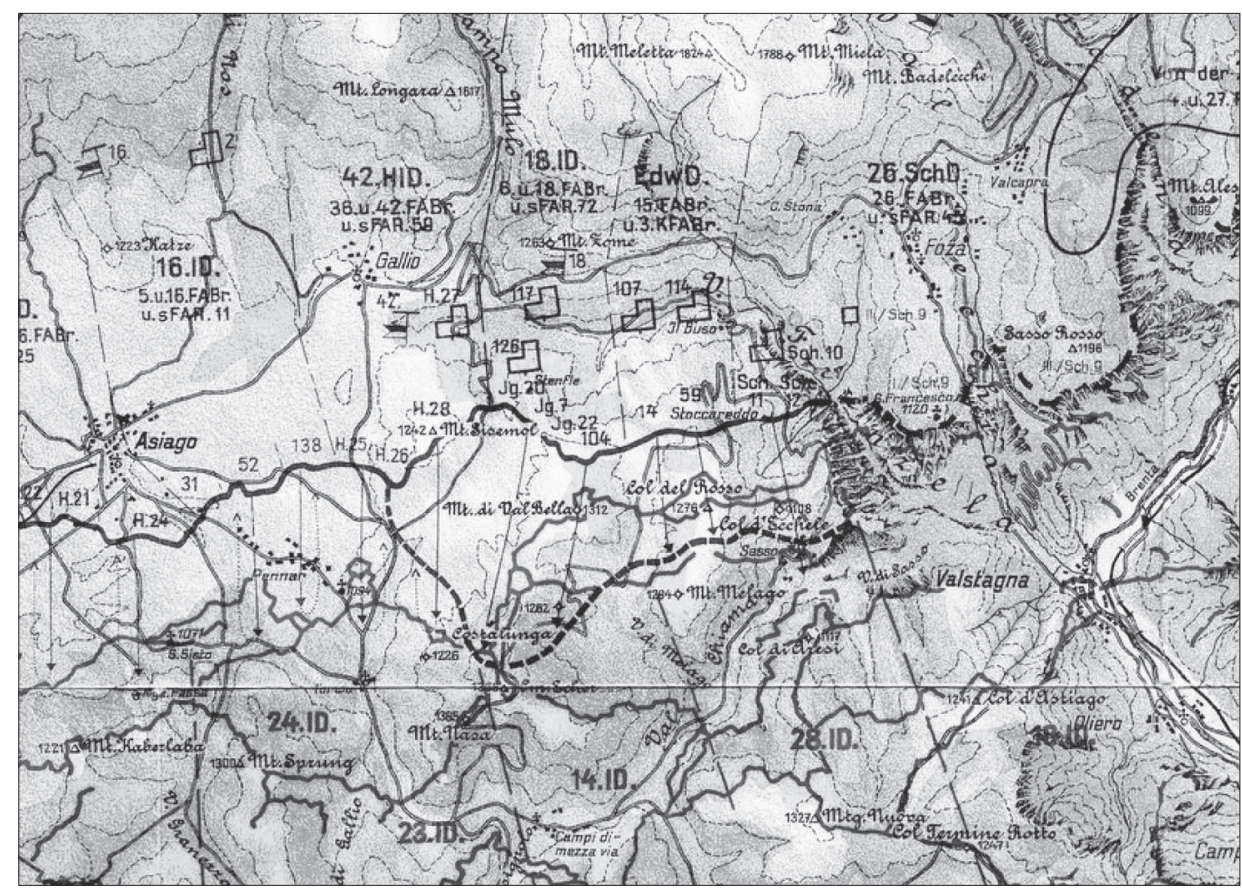

Sl. 3. Djelovanja 11. armije tijekom 15. lipnja 1918. s prikazom proboja 42. domobranske PD (42. HID) (izvor: ÖULK VII, 1938, Prilog 15, dio)

Borojevićeva skupina preslaba. Sve nade ulažu se u snage 11. armije i ona dobiva zadaće da pripremi novi napad u sektoru njezina XXVI. korpusa i zbog toga se provodi preraspodjela snaga. ${ }^{15}$

Tijekom noći 15. na 16. lipnja 11. armija nije bila uključena u veće borbe. $\mathrm{Na}$ visoravni Sedam Općina (Sieben Gemeinde) austrougarski III. korpus i glavnina zagrebačkog XIII. korpusa povukli su se na početne pozicije. Francuska 24. pješačka divizija iz XII. korpusa vodila je uspješne borbe kod sela Pennar i kapelice na koti 1094, dok su na desnom krilu bili potisnuti od strane hrvatske 42. domobranske pješačke divizije. Tijekom 17. lipnja, nakon žestokih protivničkih napada, 42. domobranska pješačka divizija morala je napustiti položaje na Costalungi. Ujutro 19. lipnja provedena je vrlo jaka talijanska topnička priprema u sektoru naših domobrana oko planina Sisemol i Val di Bella. Nakon ovih djelovanja zavladalo je relativno zatišje.

15 Österreich-Ungarns letzter Krieg, 1914. - 1918. (ÖULK) Vol. 7, Das Kriegsjahr 1918, 1938, 284. 
I u zoni odgovornosti Borojevićeve grupacije došlo je do pokretanja napada i uspostave nekoliko mostobrana preko rijeke Piave. Međutim, Talijani su spremno dočekali Borojevićev napad. Nakon nekoliko dana od svih mostobrana ostaje samo onaj kod Montella, zbog čega je tijekom 20. lipnja zapovjeđeno povlačenje. Posljednji vojnici se vraćaju na lijevu obalu tijekom 25. lipnja. Napad austrougarske vojske je propao, ali su uspjeli zarobiti 40000 Talijana. To je bila posljednja veća operacija austrougarske vojne sile u ratu. ${ }^{16}$

\section{Talijanske protumjere na planinskoj fronti (od 24. lipnja do 15. srpnja)}

Vijest da su se austrougarski vojnici evakuirali sa zapadne obale Piave za talijanske više zapovjednike bilo je olakšanje. Stoga su morali brzo djelovati na planinskom bojištu. Snažni napadi na platou Sedam općina (Sette Comunni) usmjereni su prema uzvisinama Mt. di Val Bella i Col del Rosso.

$\mathrm{Na}$ tom području Talijani su uspjeli prodrijeti u obranu. Tamo su ih dočekali dijelovi zagrebačke 53. i 126. pješačke pukovnije i još neke snage. Gubici obrane bili su vrlo veliki. ${ }^{17}$

Između 16. i 28. lipnja proveden je niz kompliciranih pokreta i rotacija snaga. Cilj je bio da se do 21. lipnja oslobodi što više snaga 11. armije za zadaće Borojevićeve grupe armija, ali je ovaj plan otkazan zbog talijanske ofenzive na rijeci Piavi. Stoga je do 28. lipnja samo dio snaga izmješten u Borojevićevu skupinu. I zagrebački XIII. korpus izdvojio je dio snaga, u sklopu čega je 42. domobranska divizija izmještena u blizinu mjesta Pergine. ${ }^{18}$

Bilo je vrlo teško zadržati položaje koji su osvojeni uz puno krvoprolića ako se neprijateljski napadi nastave. Talijani kreću u nove napade. Tijekom noći 1. na 2. srpnja dolazi do povlačenja snaga s krvlju natopljenog Mt. di Val Bella. Talijani su zauzeli vrh nakon snažne artiljerijske pripreme.

U sektoru K.u.K. 11. armije nastavljene su borbe na visoravni Asiago. Talijani, a naročito njihovi britanski i francuski saveznici, djelovali su gotovo svakodnevno. Tijekom 16. srpnja imaju manje uspjehe južno od Asiaga, da bi dva dana kasnije tijekom jutra 18. srpnja engleske i francuske snage djelovale između klanca Assa i uzvisine Mt. Sisemol na položaje III. i XIII. korpusa. ${ }^{19}$

16 D. ČUTURA - L. GALIĆ, 2004, 51.

17 Österreich-Ungarns letzter Krieg, 1914. - 1918. (ÖULK) Vol. 7, Das Kriegsjahr 1918, $1938,345$.

18 Österreich-Ungarns letzter Krieg, 1914. - 1918. (ÖULK) Vol. 7, Das Kriegsjahr 1918, $1938,346$.

19 Österreich-Ungarns letzter Krieg, 1914. - 1918. (ÖULK) Vol. 7, Das Kriegsjahr 1918, 1938, 464. 


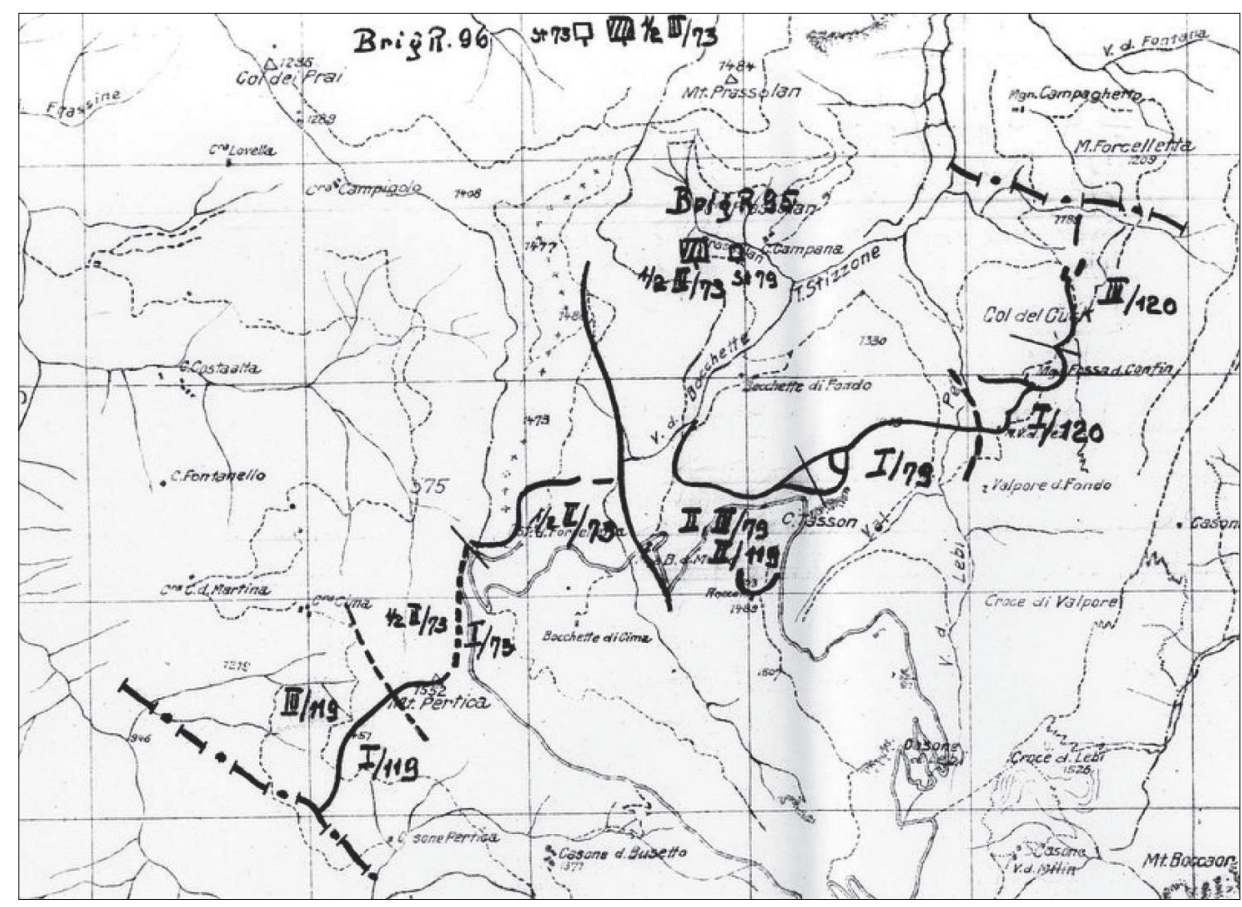

Sl. 4. Borbe "Jelačićevaca" kod Tassona. Stanje na dan 8. srpnja 1918. (izvor: ÖeStA/KA, NFA 48. I.D. 1918, kutija 2689)

"Jelačićevci" ce 6. srpnja bile prebačeni prema prvoj crti bojišta. Bore se za uzvišenje Tasson koje se nalazi istočno od važne kote Mt. Pertica. Tijekom 7. srpnja ove položaje ojačavaju II/119. i III/79. kada započinju krvavi napadi na kote 1503. i 1507. II. i III. bojna "Jelačićevaca" uspijeva osvojiti podnožje brda, ali zbog snažne talijanske obrane ne uspijevaju osvojiti vrh. Zapovjednik pukovnije pukovnik Carl Zoller nalazi se među svojim vojnicima i hrabri ih da ustraju do kraja. Sedam će puta jurišati na neprijateljske položaje prije nego što će se njihove napadne kolone u potpunosti slomiti. Zoller će u posljednjem jurišu biti teško ranjen i od zadobivenih rana će ubrzo umrijeti. Naslijedit će ga kao zapovjednik pukovnije pukovnik Kovač. ${ }^{20}$ Zbog velikih gubitaka čitava se pukovnija povlači u pozadinu na oporavak u grad Feltre. Prema izvješću od 8. srpnja "Jelačićevci" su imali 23 mrtva, od toga 2 časnika, 338 ranjenih te 23 bolesna. ${ }^{21}$

F. DUBRAVČIĆ, 2004, 156.

${ }^{21}$ ÖeStA/KA, NFA, 1. korpskommando, OpNr 188/2, 188/3 i 189/3 od 08. 07. 1918, kutija 84; NFA 48. I.D. 1918, kutija 2689 i 2693. 
"Jelačićevci" će na oporavku ostati vrlo kratko, da bi se već 15 . srpnja popunjeni i oporavljeni vratili na položaje kod Tassona. Nakon ovih teških borbi i iskazanog junaštva car Karlo im je odao priznanje: Vaše carsko i kraljevsko apostolsko veličanstvo su obavijest o junačkom vladanju 79. pješačke pukovnije u bitkama istočno od Monte Pertica uzeli sa osobitnim zadovoljstvom na znanje $i$ odaju najveće priznanje svojim davno prokušanim, hrabrim "Otočanerima". ${ }^{22}$

"Jelačićevci" do 23. srpnja imaju zabilježenih gubitaka i na položajima kod Col del Pesso (kota 1503.). Tijekom rujna i listopada imaju manje gubitke kod Mt. Pertica. ${ }^{23}$

\section{Kraj rata ipak se bliži}

Krvava ratna završnica bliži se kraju. Bugari sklapaju primirje 9. rujna. Unatoč stalnim uspjesima savezničkih snaga u Francuskoj i povećanju savezničkih snaga na talijanskom bojištu, u rujnu je talijanski načelnik Glavnog stožera general Diaz i dalje čekao povoljan trenutak za odlučnu i možda završnu ofenzivu. $^{24}$

U rujnu je bilo dosta teških lokalnih borbi u sektoru između rijeka Brente i Piave, osobito kod Mt. Asolone, Mt. Tombe, grebena Tasson i kod Mt. Pertice, ali bez značajnijeg talijanskog uspjeha. Povišena talijanska aktivnost na planinskom bojištu poklopila se s nizom rotacija snaga unutar K.u.K. 11. armije. Početkom rujna hrvatska 42. domobranska pješačka divizija, koja se odmarala u području Pergine, zamijenila je 25. pješačku diviziju, a 20. rujna veći dio njezinih snaga dolazi na područje Mt. Asolone. ${ }^{25}$

\section{Ustroj Armijske grupe Belluno}

Talijanske aktivnosti između rijeka Adige i Piave znatno su se povećale u drugoj polovici rujna. Borojevićeva grupacija je izvijestila AOK da nema sumnje da Antanta poziva Italiju na napadna djelovanja kako bi otežala austrougarsku političku situaciju i da bi mogli težište aktivnosti usmjeriti između Brente i Piave. Pripreme za ofenzivu traju mjesecima, pa moramo predvidjeti da operacija može započeti svaki čas.

22 ÖeStA/KA, NFA 48 I.D., 192/9 bez datuma za 1918.

23 HDA, Matične knjige umrlih vojnih osoba 79. pješačke pukovnije.

24 Österreich-Ungarns letzter Krieg, 1914. - 1918. (ÖULK) Vol. 7, Das Kriegsjahr 1918, $1938,473$.

25 Österreich-Ungarns letzter Krieg, 1914. - 1918. (ÖULK) Vol. 7, Das Kriegsjahr 1918, $1938,477$. 


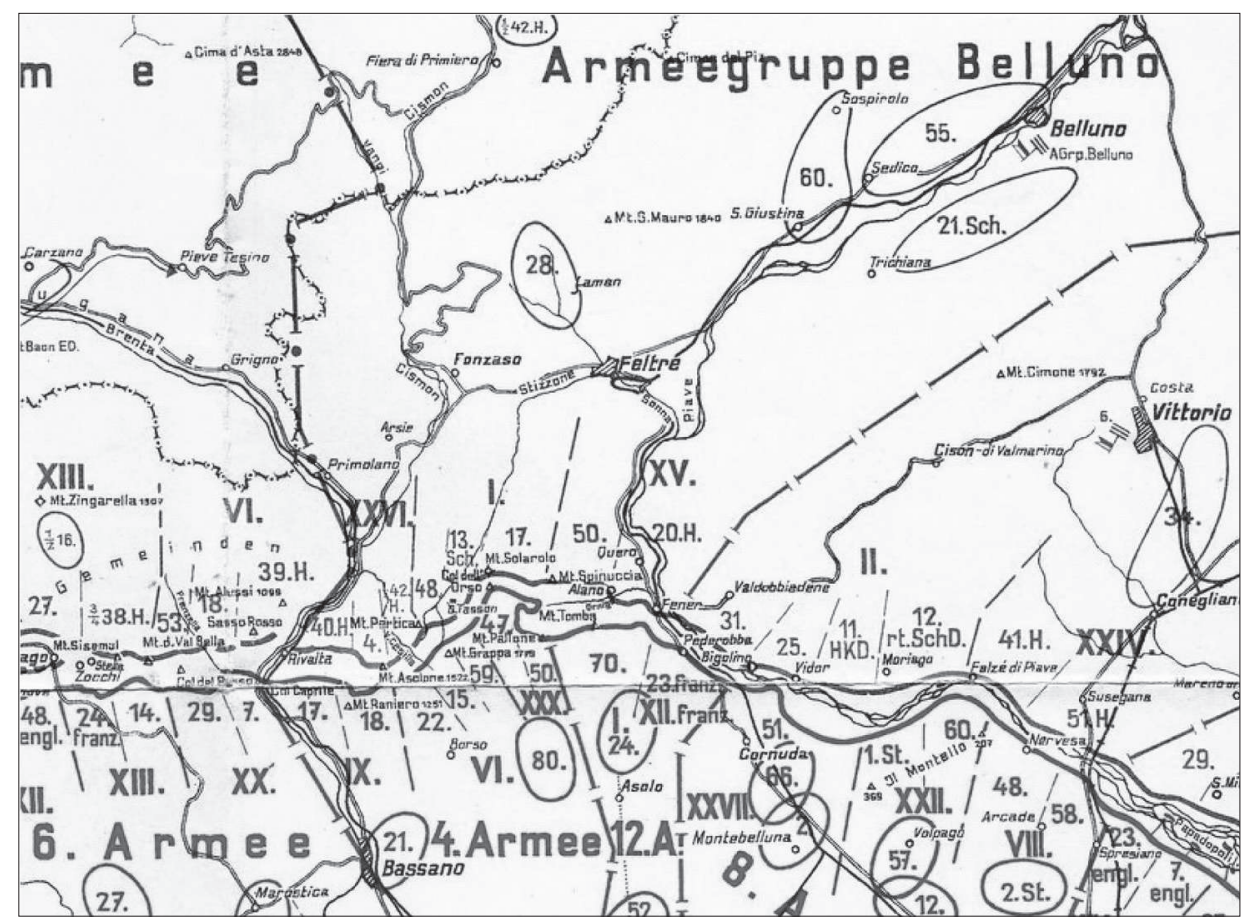

S1. 5. Armijska grupa Belluno na dan 24. listopada 1918. Pola 42. DomPD je u sastavu XXVI. korpusa kod Mt. Pertice, a ostatak kod sela Fiera di Primiero.

"Jelačićevci" su u sastavu 48. PD/I. korpusa u podnožju Mt. Grappe. (izvor: ÖULK VII, 1938, Prilog 31, dio)

Očekujući veliku talijansku ofenzivu tijekom 21. rujna, AOK je postavio strateške pričuve oko Belluna pod zapovijedanje FM Borojevića. Sljedećeg dana (22.) I. i XXVI. korpus 11. armije i XV. korpus 6. armije ušao je u novoustrojenu Armijsku grupu Belluno ${ }^{26}$ (Armeegruppe Belluno) podređenu (FM) Borojeviću, čija je glavna zadaća bila osigurati sektor između rijeka Brenta i Piave. ${ }^{27}$

AOK u Badenu bilo je zabrinuto stanjem i političkim zbivanjima u Dunavskoj monarhiji, što je moglo imati nesagledive posljedice na stanje vojske. ${ }^{28}$

\footnotetext{
26 Grupom je zapovijedao general Goglia.

27 Österreich-Ungarns letzter Krieg, 1914. - 1918. (ÖULK) Vol. 7, Das Kriegsjahr 1918, 1938, 479-481.

28 Österreich-Ungarns letzter Krieg, 1914. - 1918. (ÖULK) Vol. 7, Das Kriegsjahr 1918, $1938,570$.
} 
U Zagrebu se sastaje Narodno vijeće Države SHS, a Poljaci objavljuju osnivanje svoje samostalne države. Problemi se sve više produbljuju: gotovo sve divizije u venetskoj nizini bile su zaražene malarijom. Artiljerija i opskrba postale su gotovo nepokretne zbog nedostatka konja. Zbog katastrofalnoga razvoja stanja u Makedoniji i stanja bugarske vojske kriza se bliži svojem vrhuncu.

U prvoj polovici listopada borbe se nastavljaju oko Asiaga i Mt. Sisemola, da bi tijekom 21. listopada bio izvršen proboj na visoravni Asiago. Tijekom 15. listopada je 36. pješačka divizija u pričuvi Grupe armija, a 42. domobranska pješačka divizija je u sastavu AGr Belluno/GA Borojević. ${ }^{29}$

AOK je s velikom zabrinutošću promatralo pripreme za talijanski napad jer je Austro-Ugarska sve više zapadala u nerješivu krizu. Unutrašnja politička previranja su neizbježno utjecala na bojište, što je moglo završiti vojnom katastrofom. Počinje se razmišljati o primirju. Tijekom 11. listopada Borojevićeva skupina zaprimila je zapovijed AOK-a za evakuacijom vrijedne vojne opreme, koja nije bila potrebna za borbu, u domovinu. Htjelo se vojsku osposobiti za obranu granica Monarhije do potpisivanja primirja.

Politička situacija dramatično se mijenja: tijekom 22. listopada nadvojvoda Josip traži od Vrhovnog zapovjedništva da se sve mađarske snage vrate u domovinu pod izlikom njezine obrane od Rumunjske i Srbije. Hrvatski sabor donosi 29. listopada donosi odluku o razrješenju svih državno-pravnih odnosa s Austrijom i Ugarskom.

Treba napomenuti da je tijekom 24. listopada pola 42. domobranske pješačke divizije u sastavu XXVI. korpusu/AGr Belluno, a druga polovina u pričuvi, da bi nakon toga krenula prema selu Fiera di Primiero, sjeverno od bojišta divizije. ${ }^{30}$

Posljednja bitka austrougarske vojske: obrambena pobjeda na Grappi, 24. - 28. listopada

Tijekom 24. listopada, točno godinu dana nakon proboja kod Kobarida, Talijani su započeli svoju dugo pripremanu napadnu aktivnost između rijeka Brente i Piave. Oblaci i magla iznad visokih planina zamaglili su žestoke borbe koje su bjesnile na području Grappe.

29 Österreich-Ungarns letzter Krieg, 1914. - 1918. (ÖULK) Vol. 7, Das Kriegsjahr 1918, 1938, Prilog 32.

30 Österreich-Ungarns letzter Krieg, 1914. - 1918. (ÖULK) Vol. 7, Das Kriegsjahr 1918, 1938, Prilog 31. 
Činilo se da je tamo stigla stara habsburška vojska. Tisuće oružja je zagrmjelo kao uvod u strašnu simfoniju, koja je najavila posljednju vojnu aktivnost nesretne austrougarske vojske. Nakon snažne vatre koja je dosegla najveću snaga oko 7 sati, talijansko pješaštvo kreće u odlučujući napad. Šest divizija talijanske 4. armije napredovalo je u zoni Armijske grupe (AGr) Belluno između Col. Caprile i Mt. Spinuccia. Slijedile su dvije divizije 12. talijanske armije na području Mt. Tombe. Austrougarska vojska na prvoj crti obrane je bez obzira na glad i neimaštinu čekala kraj rata. Znali su da su mirovni pregovori neizbježni te su se odlučili dostojno oduprijeti neprijatelju, ulažući svoju posljednju snagu i hrabrost bez obzira na nacionalnost. Nijemci, Mađari, Poljaci, Česi, Hrvati, Srbi, Rumunji, Slovenci i Slovaci - svi su još jednom zajedno stajali na obrambenim linijama. I tako se dogodilo čudo. U danima teških bitaka talijansku 4. armija zaustavili su pripadnici Armijske grupe Belluno. To se isto dogodilo i u sljedeća dva dana.

U tim će se borbama tijekom 25. listopada istaknuti snage naših domobrana kod Mt. Asolone, osobito sisačke 27. domobranske pješačke pukovnije. Od 1:00 do 13:30 talijanske baterije svih kalibara udarale su svom žestinom po planini. U 15 sati neprijateljsko pješaštvo krenulo je u novi proboj. Uspjeli su prodrijeti u razmještaj 4. pješačke divizije na istočnoj strani Mt. Asolone, ali su odbačeni zahvaljujući hrabrim braniteljima. Zbog junaštva pješaštva i briljantnoga djelovanja obrambenoga topništva te večeri sve su fortifikacije ostale u rukama K.u.K. XXVI. korpusa. ${ }^{31}$

26. listopada I. korpus, u čijem je sastavu lička 79. pješačka pukovnija "Jelačićevci" (48. pješačka divizija), došao je pod snažan udar na Mt. Pertici kao i susjedni XXVI. korpus. Tijekom jutra Talijani su duboko ušli u razmještaj 48. pješačke divizije te u bok i stražnju stranu 42. domobranske pješačke divizije prema dolini Cesilla. Osječka 28. domobranska pješačka pukovnija spašena je od obuhvata zahvaljujući snažnom protunapadu pričuva 28. i 42. domobranske pješačke divizije. Ove snage uspjele su se probiti neposredno ispod vrha Mt. Pertica, koje su još držali ostaci češke 73. pješačke pukovnije iz Cheba (njem. $E_{\text {Eger }}{ }^{32}$, koji ih odbijaju. Time su Talijani spriječeni u osvajanju ovoga područja. U daljnjim bezuspješnim napadima talijanska 4. armija potpuno je iscrpila svoju snagu. Napadi na Mt. Perticu i okolne uzvisine stajale su ih gotovo 35.000

31 Österreich-Ungarns letzter Krieg, 1914. - 1918. (ÖULK) Vol. 7, Das Kriegsjahr 1918, 1938, 598-601.

32 Österreich-Ungarns letzter Krieg, 1914. - 1918. (ÖULK) Vol. 7, Das Kriegsjahr 1918, 1938, 603. 
poginulih, ranjenih i nestalih, što je faktički za njih bio poraz. Time je Armijska grupa Belluno ispunila svoju zadaću. FM Borojević zahvalio je vojnicima AGr Belluno i prepoznao njihovo herojsko držanje i iznimnu hrabrost. Iznenađujuća obrambena pobjeda na planinama Grappe uvelike je povećala povjerenje feldmaršala Borojevića. Dala mu je osnove za vjerovanje da će još uvijek zadržati položaje dok se ne stvore uvjeti za primirje. ${ }^{33}$

Međutim, njegovo samopouzdanje uskoro su pokvarile vijesti iz Tirolske fronte is rijeke Piave.

Dolazak hrvatske 36. pješačke divizije na rijeku Piave i početak vojnih pobuna

Tijekom 27. listopada talijanske snage sastava:12., 8. i 10. armija počele su prelaziti rijeku Piave težišno u sektoru K.u.K. 6. armije koja je u početku odbila sve napade. Tijekom noći 27. na 28. listopada Talijani su uspjeli dublje ući u austrougarski razmještaj kod Sernaglije i nasuprot riječnog otoka Papadopoli što je poremetilo sustav obrane, ali bez težih posljedica. Ishod će u konačnici ovisiti o tome mogu li raspoložive pričuve pristići i početi djelovati na vrijeme. Oba zapovjednika armija Borojevićeve skupine ${ }^{34}$ nadali su se da mogu eliminirati izbočine koje je neprijatelj stvorio.

Dok je bitka bjesnila na Piavi, došlo je do rasula sustava vođenja i zapovijedanja, koje je započelo s pobunom južnoslavenskih i mađarskih pukovnija na Tirolskoj fronti, da bi se ubrzo proširila i na Borojevićeve snage. To je bio utjecaj vrlo dinamičnih političkih zbivanja u unutrašnjosti države. Tijekom 23. listopada došlo je do pobune među hrvatskim domobranima iz zagrebačke 25. i karlovačke 26. pješačke pukovnije. Zanimljiva je pobuna Čeha koji su svojim vojnicima podijelili letke na kojima je pisalo: Stanite! Nećemo više ići naprijed! Nezavisnost je proglašena u Češkoj!35

Tako je u Armijskoj grupi Belluno veliki dio postrojbi izvan prvih crta bio potpuno nepouzdan za borbu, dok su vojnici na bojišnici bili i dalje uspješni u borbama pokazujući veliko junaštvo. Istovremeno se i naši "Jelačićevci" bune u Rijeci. ${ }^{36}$

33 Österreich-Ungarns letzter Krieg, 1914. - 1918. (ÖULK) Vol. 7, Das Kriegsjahr 1918, 1938, 605 .

${ }_{34}$ Ova se Grupa armija sastojala od AGr Belluno, 6. i Sočanske armije.

35 Österreich-Ungarns letzter Krieg, 1914. - 1918. (ÖULK) Vol. 7, Das Kriegsjahr 1918, 1938,630 .

36 O tome više N. TOMINAC, 2012, 283-322. 
Tijekom noći 28. na 29. listopada AOK je dao zapovijed podmaršalu Borojeviću da se spriječi uništavanje vojske i pravodobnim povlačenjem pokuša izbjeći katastrofalan poraz. 29. listopada Talijani su na Južnotirolskom bojištu, posebno na visoravni Asiago, i dalje ograničavali svoje aktivnosti na vezivanju svojih protivnika. Bitka u venetskoj nizini bjesnila je punom žestinom. $\mathrm{Na}$ planinama Mt. Grappe talijanska je 4. armija nakon pristizanja ojačanja obnovila svoje napade na AGr Belluno u nadi da će nakon uspjeha na Piavi i ondje napokon pobijediti. Situacija postaje iznimno kritična, osobito nakon uspjeha Britanaca u sektoru K.u.K. XVI. korpusa. Nedisciplina vojske nije dozvoljavala uspostavu kvalitetne obrane..$^{37}$

Tijekom istoga dana prednje linije Borojevićeve skupine razbijene su na pojedinim mjestima. Situacija je postala beznadna. U blizini Belluna okupljala se masa vojske koja je krenula prema svojim kućama. Među njima su i 25. i 26. domobranska pješačka pukovnija iz 42. domobranke pješačke divizije koje su se kretale selom Fiera di Primiero. ${ }^{38}$

\section{Povlačenje i raspad austrougarske vojske od 30. listopada do 2. studenoga}

Zbog kaosa u unutrašnjosti Monarhije i raspada vojske i mornarice, 29. listopada K.u.K. visoko zapovjedništvo bilo je uvjereno da je nemoguće nastaviti daljnje borbe. Stoga je zapovjeđeno FM Borojeviću da evakuira venetsku ravnicu te izbjegne direktne borbe s Talijanima i njihovim saveznicima. Dok su se lomile linije 6. armije i desnog krila Sočanske armije, još je uvijek AGr Belluno držala svoje položaje na Col. Caprileu i na gorju Asolone, Pertici i Spinuccii i tamo pružala snažan otpor. To je bila jedina nada da se ublaži poraz.

Međutim, situacija ove grupacije postala je neodrživa tijekom 29. listopada kada se 6. armija povukla preko brdovitog kraja Vittorija i Conegliana prema rijeci Livenzi, čime se otvorila praznina između XV. korpusa/AGr Belluno i 6. armije. Stoga su snage koje su odlučno branile područje Grappe bile u opasnosti da budu okružene i odsječene od svojih linija povlačenja koje su vodile kroz gradić Feltre i područja grada Belluna. Ova kritična situacija nalagala je zapovjedniku skupine da zapovijedi povlačenje. Ali GdI Horsetzky, zapovjednik K.u.K. XXVI. korpusa, zamolio je zapovjednika armijske skupine odgodu povlačenja najmanje $1938,640$.

37 Österreich-Ungarns letzter Krieg, 1914. - 1918. (ÖULK) Vol. 7, Das Kriegsjahr 1918,

38 Österreich-Ungarns letzter Krieg, 1914. - 1918. (ÖULK) Vol. 7, Das Kriegsjahr 1918, 1938,642 . 
za jedan dan. Kasnije je napisao u svojim memoarima: Nismo mogli jednostavno napustite pozicije koje su tisuće naših hrabrih ljudi obranili posljednjih šest dana po cijenu vlastitih života. Nenadano povlačenje nesumnjivo bi dovelo do pada morala i kaosa. ${ }^{39}$ Zapovjednik K.u.K. 11. armije također je zatražio od armijske grupe da održi položaje. Stoga je FZM Goglia odlučio odgoditi početak povlačenja do noći 30. na 31. listopada. Tada dio vojnika iz pričuve odbija zapovijed preuzeti položaje između Mt. Cesen i Col. Vernada što je zaprijetilo da se Talijani probiju iz doline Piave do Cesane i Mel i onemogućavanja povlačenja većine snaga preko Belluna. Tijekom te napete noći FZM Goglia je izvijestio AOK u Badenu: Postoji samo jedan način da spasimo hrabre borce od srama kapitulacije - neposredno primirje. ${ }^{40}$

Hrabri vojnici, među njima i naši "Jelačićevci" i domobrani kod Mt. Pertice, na prvoj crti između uzvisina Col. Caprile i Mt. Spinuccia tijekom 30. listopada odbijaju sve talijanske napade uz teške gubitke i tako ostaju nepokolebljivi branitelji Grappe. No, austrougarske snage u venecijanskim ravnicama su poražene i odvojene od planine. Tijekom istoga dana talijanske snage u dolini Piave kod mjesta Quero na Piavi prodiru prema brdima zbog čega je FZM Goglia shvaća da je krajnje vrijeme da prekine bitku i zapovijeda povlačenje.

Povlačenje je trebalo ići dolinom Sugana, a zatim dalje prema sjeveru preko Mt. Salubio, Val piana i vrhova Fažanskih Alpa (Fassana Alpe). Prolazi su trebali biti provedeni preko prijevoja visokih iznad 2000 metara bez hrane, odjeće i drugih nužnih potrepština. Glad će prouzročiti gubitak discipline. Dolina rijeke Piave već je bila opljačkana. Nadalje, vojska nije navikla na duge hodanje nakon dugih mjeseci pozicijskoga ratovanja i slabe fizičke aktivnosti. ${ }^{41}$

Oko ponoći (30. na 31. listopada) hrabri branitelji Col Caprilea i Asolone, Pertica i Spinuccia napustili su krvavo natopljeno bojno polje. Među njima je bio dio naših domobrana i "Jelačićevci". Borili su se do zadnje snage odnoseći zadnju obrambenu pobjedu umiruće K.u.K. vojske. Uvečer 31. listopada glavnina AGr Belluno uspjela je u posljednjem trenutku izbjeći prijetnju zarobljavanja, osim izoliranih skupina koje su se zaustavile zbog iscrpljenosti.

39 Österreich-Ungarns letzter Krieg, 1914. - 1918. (ÖULK) Vol. 7, Das Kriegsjahr 1918, 1938, 667-668.

40 Österreich-Ungarns letzter Krieg, 1914. - 1918. (ÖULK) Vol. 7, Das Kriegsjahr 1918, 1938, 667.

41 Österreich-Ungarns letzter Krieg, 1914. - 1918. (ÖULK) Vol. 7, Das Kriegsjahr 1918, 1938, 668-671. 
Tijekom 1. studenoga AGr Belluno nastavlja svoje povlačenje. Tako se zagrebačka 25. i karlovačka 26. domobranska pješačka pukovnija zajedno sa zapovjedništvom 42. domobranske pješačke divizije probija preko prijevoja Rolle i kroz dolinu Fassa do Arabba i Corvara. Nedostatak vlakova i kaos koji je zavladao u novoosnovanim državama onemogućili su brz transport nediscipliniranih postrojbi, osobito čeških i južnoslavenskih iz doline Puster u njihove domovine. Zbog toga je u toj dolini zaprijetio potpuni kaos, pljačka i napadi na vlakove koji će zaustaviti željeznički promet i isporuku potrepština. Predstavnici novih nacionalnih država trebali su odmah poslati kompozicije, ali bez uspjeha. ${ }^{42}$

\section{Kraj rata na Jugozapadnom bojištu}

Tijekom noći 2. na 3. studenog stigla je zapovijed K.u.K. AOK o prestanku borbi. Vojnici su primili zapovijedi o prekidu vatre 3. studenog između 7 i 8 sati. Sve su pukovnije marširale prema domovini. Tako je 42. domobranska pukovnija prošla kroz Predazzo, a njezine pobunjene pukovnije, one iz 83. domobranske pješačke brigade - zagrebačka 25. i karlovačka 26. pješačka pukovnija, već su bile blizu Brunecka u dolini Puster kao i dijelovi 48. pješačke divizije s "Jelačićevcima". I ovdje nastupa kaos: nedisciplinirana vojska počela je ubijati i pljačkati. FZM Goglia zatražio je energičnu akciju novih vlada i nacionalnih vijeća, osobito uspostavu željezničkog prometa. Motorizirane kolone zaustavljene su zbog nedostatka benzina, a AOK nije imao nikakvih sredstava za pružanje bilo kakve pomoći. ${ }^{43}$

Oko podneva 4. studenog, iz Padove je pristigla radosna vijest građanima Italije: Austrougarska vojska je uništena. Zarobljeno je 300.000 vojnika i oko 5000 topova i masa vojne opreme. Prema talijanskim izvješćima do 11. studenog utvrđeno je 436.674 ratnih zarobljenika. Posebno bolna bila je smrt velikog broja (30.000) zarobljenih vojnika koji su podlegli bolesti tijekom neočekivano dugoga razdoblja zatočeništva. ${ }^{44}$

42 Österreich-Ungarns letzter Krieg, 1914. - 1918. (ÖULK) Vol. 7, Das Kriegsjahr 1918, 1938, 695.

43 Österreich-Ungarns letzter Krieg, 1914. - 1918. (ÖULK) Vol. 7, Das Kriegsjahr 1918, 1938, 744-746.

44 Österreich-Ungarns letzter Krieg, 1914. - 1918. (ÖULK) Vol. 7, Das Kriegsjahr 1918, 1938, 758. Brojke koje prikazuju broj austrougarskih zarobljenika između 24. listopada i 4. studenoga variraju između 400.000 i 480.000 ljudi. Prema R. CARLO, 1934, 389 zarobljeno je 483.000 vojnika i 7.571 top. Isto: E. RATZENHOFER, 1931, 837. 
Vojnici Armijske grupe Belluno nastavili su povlačenje kroz Dolomite u dolinu rijeke Puster, a oni iz 6. armije koji su izbjegli zarobljavanje povukli su se kroz Pontafel i prijevoj Predel u gornji tok rijeke Drave. Čitav prostor sve do grada Villacha bio je opljačkan, pa je nakon dva dana talijanska vlast zamoljena za pomoć u hrani. Sve su željezničke postaje bile pune vojnika i opreme, a ceste automobila i kamiona. Mnoge lokalne vlasti i građani sudjelovali su u pljački vojske. Nastao je šverc vojne opreme kojom se htjelo doći do hrane. U drugom tjednu studenoga ogromne mase vojnika dolazile su do austrijskih riječnih dolina i područja Villacha i Ljubljane. Tijekom 5. studenoga posljednji zajednički ministar rata stare i sada nestale države, general pukovnik GO Stöger-Steiner, pripremio je nalog za demobilizaciju vojske.

Masovni pokreti vojske prema novonastalim državama konačno su započeli 6. studenoga. Taj ogroman prijevoz trajao je do sredine studenoga. Oko 800.000 ljudi vratilo se u svoje domove, najvećim dijelom pješice. ${ }^{45}$

\section{Zaključenje primirja}

Stravični zvukovi bitaka prestali su 11. studenoga 1918. u 11 sati kada su prestala neprijateljstva između Njemačke i Francuske. Ostale zaraćene strane su dotad već imale potpisana primirja i više nisu ratovale.

Nova era mira i prosperiteta za čovječanstvo trebala je početi. Habsburška monarhija doživjela je potpuni nestanak, ali nije došlo do tragičnih događaja poput revolucije i građanskoga rata kao u Rusiji. Rat za ovu državu nije bio samo borba za njezino održavanje kao velike sile, već doslovce borba za njezino postojanje poput još tri carstva - ruskoga, osmanskoga i njemačkoga, koja su također nestala u ovome ratu.

Ovom prilikom posvetili smo pažnju ličkim pješačkim postrojbama koje su sudjelovale u ovim već pomalo zaboravljenim događanjima iz Velikog rata. Tako će taj tragičan povijesni period postati dio našega povijesnog sjećanja, a time ćemo odati dostojnu počast brojnim žrtvama s ovoga područja.

45 Österreich-Ungarns letzter Krieg, 1914. - 1918. (ÖULK) Vol. 7, Das Kriegsjahr 1918, $1938,764$. 


\section{Literatura}

Rocca CARLO, Vittorio Veneto il Corbaccio, Milano, 1934.

Dinko ČUTURA - Lovro GALIĆ, Veliki rat: pregled ratnih operacija, Hrvatska revija, 3, Zagreb, 2004, 13-60.

Frane DUBRAVČIĆ, Živ sam i dobro mi je (ratni dnevnik pripadnika 79. pukovnije), Otočac, 2004.

Feldmaršal Svetozar barun Borojević od Bojne (1856. - 1920.), zbornik radova, ur. Marino Manin, Zagreb, 2011.

Österreich-Ungarns letzter Krieg, 1914. - 1918. (ÖULK) Vol. 7, Das Kriegsjahr, 1918., Bundesministerium für Heereswesen und vom Kriegsarchiv, Beč, 1938.

Milan POJIĆ, Vojskovođa Svetozar Boroević, katalog povodom 150. obljetnice rođenja, HDA, Zagreb, 2006.

Milan POJIĆ, Ustroj Austrougarske vojske na ozemlju Hrvatske 1868. - 1914., Arhivski vjesnik, 43, Zagreb, 2001.

Emil RATZENHOFER, Waffenstillstand von Villa Giusti, Beč, 1931.

Nikola TOMINAC, 79. pukovnija Zajedničke vojske u Prvome svjetskom ratu, 1918. u hrvatskoj povijesti: zbornik radova sa znanstvenog skupa održanog u palači Matice hrvatske 29.-30. listopada 2008, ur. Željko Holjevac, Zagreb, 2012, 283322 .

Arhivsko gradivo

Hrvatski državni arhiv (HDA), Matične knjige umrlih vojnih osoba 79. pješačke pukovnije za vrijeme 1914. - 1919.

Österreichisches Staatsarchiv (ÖeStA) - Kriegsarchiv (KA), Wien: Neue Feld Akten (NFA) Gefehtsbericht za IR 79 i 48. I.D.

ÖeStA/KA, Verlustliste IR 79. 


\section{LIKA INFANTRY UNITS IN THE AUSTRO-HUNGARIAN MILITARY IN BATTLES DURING 1918}

\section{Summary}

This contribution is dedicated to the $100^{\text {th }}$ anniversary of the First World War and members of the $79^{\text {th }}$ Infantry Regiment of the Joint Forces from Otočac (K.u.K. Otočaner Infaterieregiment Graf Jellačić Nr. 79.), more famous as the "Jelačićevci" and the $26^{\text {th }}$ Homeland Infantry Regiment from Karlovac from $42^{\text {nd }}$ Homeland Infantry Division in whose formation was the third battalion of men from Lika from Gospić. In it is described their participation in the last year of the war.

On the basis of available specific literature and source archive material from the holdings of the Austrian state archive - Österreichisches Staatsarchiv (ÖeStA) - Kriegsarchiv (KA) and the Croatian State Archive in Zagreb (HDA), primarily from the preserved operational documentation, battle reports, lists of the losses, registry books of the dead and other available documentation, the author processes the course of the battles during 1918, in other words, the last year of the war. The military terminology has been adapted to today's official Croatian terminology, and where that was not possible the Croatian and Austro-Hungarian terms are cited alongside each other, particularly for military ranks and formations.

Keywords: Croatia military history, First World War, southwest battlefield, $79^{\text {th }}$ Infantry Regiment of the Joint Forces 'Grof Josip Jelačić' Otočac, K.u.K. 48. 48 ${ }^{\text {th }}$ Infantry Division (K.u.K. 48 ID), $42^{\text {nd }}$ Homeland Infantry Division, $26^{\text {th }}$ Homeland Infantry Regiment Karlovac. 